\title{
PENGARUH SENAM AEROBIK TERHADAP KEJADIAN PREMENSTRUAL SYNDROME (PMS) PADA MAHASISWI JURUSAN KEPERAWATAN TANGERANG
}

\author{
*Ema Hikmah
}

\begin{abstract}
Abstrak
Salah satu kondisi kesehatan reproduksi adalah terkait dengan menstruasi. Keadaan yang dialami oleh wanita pada saat mengalami menstruasi berbeda-beda. Gangguan yang dialami menjelang wanita menstruasi disebut PMS (Premenstrual Syndrome). Penelitian ini diharapkan dapat mengetahui pengaruh senam aerobic terhdap kejadian PMS. Penelitian ini menggunakan desain penelitian kuasieksperimen. Desain kuasi-eksperimen dalam penelitian menggunakan tipe onegroup design dengan pre dan post test. jumlah responden sebanyak 87 orang. Analisis data dalam penelitian ini menggunakan uji $t$. Hasil penelitian pada kelompok intervensi diketahui ada penurunan angka kejadian PMS yaitu nilai rerata sebelum dilakukan senam aerobic yaitu 11,49 dengan standar deviasi 2,841 dan setelah dilakukan senam aeorobik adalah 6,78 dengan standar deviasi 2,713 dengan $p$ value $=0,000 \alpha=0,05$. Hasil yang signifikan pada penelitian ini menunjukan bahwa hal ini bermakna apabila senam aerobik dilakukan maka angka kejadian PMS akan menurun.
\end{abstract}

Kata kunci : Senam aerobik, Angka kejadian PMS, Pre-post Study

*Poltekkes Kemenkes Banten

\section{EFFECT OF AEROBIC EXERCISE ON THE ACCIDENT OF PREMENSTRUAL SYNDROME FOR STUDENT OF NURSING DEPARTEMENT TANGERANG \\ *Ema Hikmah}

\begin{abstract}
One of the reproductive health conditions are associated with menstruation. The experienced by women during menstruation varies. Disruption experienced ahead of menstruating women are called PMS (Premenstrual Syndrome). This study is expected to determine the effect of aerobic exercise on the incidence of PMS. This study used a quasi-experimental research design. Quasi-experimental design in the study using onegroup type design with pre and post test. the number of respondents as many as 87 people. Analysis of the data in this study using the $t$ test. Results of research in the intervention group is known to have a decrease in the incidence of PMS is the average value prior to aerobic exercise is 11.49 with a standard deviation of 2.841 and after exercise aeorobik is 6.78 with a standard deviation of 2.713 with $p$ value $=0.000 \alpha=0.05$. A significant result of this research shows that it is significant when aerobic exercise is done then would decrease the incidence of PMS.
\end{abstract}

Key words; Aerobic Exercise, Premenstrual Syndrom, Pre-Post Study 


\section{Pendahuluan}

Kesehatan reproduksi pada wanita penting diperhatikan terkait dengan factor kesuburan wanita tersebut. Salah satu kondisi kesehatan reproduksi adalah terkait dengan menstruasi. Keadaan yang dialami oleh wanita pada saat mengalami menstruasi berbeda-beda. Gangguan yang dialami menjelang wanita menstruasi disebut PMS (Premenstrual Syndrome). (Paramita, 2010)

Tanda dan gejala PMS pada setiap wanita berbeda-beda, ada yang ringan sampai berat. Gejala yang biasanya dirasakan oleh wanita tersebut dapat berupa gangguan fisik dan psikologis. Gangguan fisik dapat berupa lemah, lesu, mual, muntah, kembung, sakit pada daerah payudara, perut, pinggang dan area kewanitaan, sedangkan gangguan psikologis dapat berupa hilangnya mood, tidak bergairah, mood yang tiba-tiba berubah, sensistif, mudah marah dan cenderung apatis. (Andira,2010)

Penyebab PMS sampai saat ini belum dapat dipaparkan dengan jelas, tetapi pendapat sementara penyebab PMS ini adalah sebagai berikut: Perubahan hormonal dan neurotransmitter, pola makan yang buruk dan konsumsi obat-obatan tertentu, Gaya hidup yang kurang baik, misalnya kurang melakukan aktivitas fisik, Kadar hormon estrogen dalam darah meningkat sehingga menimbulkan gejala depresi, Kadar hormon serotonin menurun karena adanya perubahan jumlah hormon estrogen., dan Adanya keterkaitan antara PMS dan status gizi seorang wanita yang akan mengalami haid, 2 minggu menjelang haid, rata-rata setiap wanita mengalami 2 hal yang dianggap bisa mempengaruhi metabolisme energinya. Hal tersebut adalah meningkatnya laju metabolik dasar pada saat tidur dan meningkatnya selera makan. Hal ini pernah dibuktikan melalui suatu penelitian yang menunjukkan bahwa wanita yang akan mengalmi masa haid, mengonsumsi 300 kalori lebih banyak pada waktu 10 hari menjelang masa haidnya (Nurchasanah, 2009). 
Gangguan-gangguan yang dialami wanita pada saat PMS dapat mengganggu aktifitas, baik yang bersekolah maupun yang sudah bekerja. Beberapa penelitian telah ada yang membahas mengenai tindakan yang dapat dilakukan untuk mengatasi PMS. Tindakan tersebut dapat berupa aktifitas fisik seperti berolahraga maupun dengan memperhatikan asupan gizi pada wanita tersebut. Kebiasaan yang b aik seperti aktifitas dan olahraga dapat mempengaruhi timbulnya PMS. Kurang berolahraga dan aktivitas fisik menyebabkan semakin beratnya PMS. (Saryono, 2009).

Berdasarkan survey awal yang dilakukan pada mahasiswi Jurusan Keperawatan Tangerang di dapatkan hasil lebih dari 50\% mahasiswa mengalami PMS. Kenyataan tersebut membuat peneliti tertarik untuk melakukan penelitian yang berjudul "Pengaruh Senam Aerobic terhadap Kejadian Premenstrual Syndrome (PMS) pada Mahasiswi Jurusan Keperawatan Tangerang Poltekkes Banten.

Penelitian ini bertujuan mengiidentifikasinya pengaruh senam aerobik terhadap kejadian PMS pada mahasiswa Jurusan Keperawatan Tangerang.

\section{Metode Penelitian}

Penelitian ini menggunakan desain penelitian kuasi-eksperimen, dengan menggunakan tipe nonequivalent kontrol group design dengan pre dan post test. Intervensi yang diberikan adalah memberikan senam aerobik diberikan pada kelompok perlakuan, sedangkan pada kelompok kontrol tidak. Sampel dalam penelitian ini berjumlah 89 mahasiswa yang terdiri dari 45 mahasiswa kelompok intervensi dan 42 mahasiswa kelompok kontrol. kriteria pemilihan dimasukkan dalam penelitian sampai jumlah subyek penelitian terpenuhi.

Kegiatan penelitian ini meliputi tindakan senam aerobik pada kelompok intervensi 2 kali dalam seminggu, selama 30 menit, dalam waktu satu bulan.

Analisis data dalam penelitian ini diolah dengan program statistik. Analisis bivariat untuk sampel berpasangan digunakan uji t-test dependen dan untuk data yang tidak 
berpasangan dilakuakan uji t-tes independen.

\section{Hasil Penelitian}

Selama pengumpulan data yang dilakukan mulai bulan Mei sampai Nopember 2015.

Jumlah responden penelitian sebanyak 87 responden yaitu 45 responden pada kelompok kontrol dan 42 responden pada kelompok intervensi.

\section{Tabel 1}

Perbandingan Nilai Kejadian PMS pada kelompok kontrol saat pre-test dan posttest pada mahasiswi Jurusan Keperawatan Tangerang Tahun 2015
Tabel 2

Perbandingan Nilai Kejadian PMS pada kelompok kontrol saat pre-test dan posttest pada mahasiswi Jurusan Keperawatan Tangerang Tahun 2015

\begin{tabular}{llc}
\hline & \multicolumn{2}{c}{ Kelompok Kontrol } \\
& Pre Intervensi & Post Intervensi \\
\hline Mean & 9,24 & 9,43 \\
SD & 3,176 & 3,062 \\
Minimal & 3 & 3 \\
Maksimal & 17 & 17 \\
& & \\
\hline
\end{tabular}

Tabel 2. menunjukkan nilai pre-test rerata angka kejadian PMS pada kelompok kontrol adalah 9,24, sedangkan saat post-test nilai rerata 9,43, hal ini menunjukan pada nilai rerata terjadi peningkatan sedikit setelah dilakukan post-test.

\begin{tabular}{|c|c|c|}
\hline \multicolumn{3}{|c|}{ Kelompok Intervensi } \\
\hline & Pre Intervensi & Post IntervensiDia \\
\hline Mean & 11,49 & $6,78 \quad$ kej \\
\hline SD & 2,84 & 3,71 \\
\hline Minimal & 3 & 1 \\
\hline Maksimal & 16 & 12 \\
\hline
\end{tabular}

Tabel 1. menunjukkan bahwa nilai rerata angka kejadian PMS pada kelompok intervensi sebelum dilakukan senam aerobic adalah 11,49, sedangkan setelah Diagram 4.1 Diagram Distribusi Rerata Frekuensi angka kejadian PMS pada Kelompok Intervensi dan Kontrol Sebelum dan Setelah dilakukan intervensi

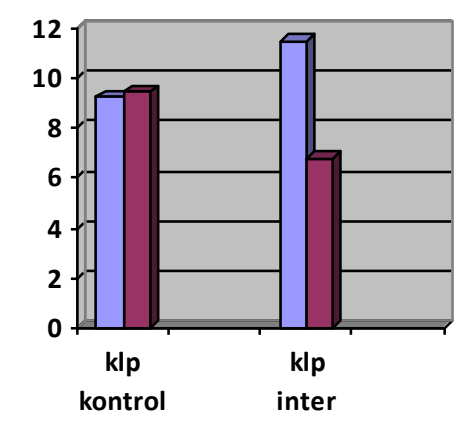

dilakukan senam aerobic nilai rerata menjadi 6,78, sehingga terjadi penurunan pada nilai rerata sebelum dan sesudah dilakukan intervensi.

\section{Perbandingan rerata selisih angka \\ kejadian PMS sebelum dan setelah senam aerobik pada kelompok Intervensi dan kelompok kontrol.}


Perbandingan rerata angak kejadian PMS diidentifikasi sebagai selisih nilai pre-tes dan post-test ada masing-masing kelompok.

Tabel 3

Perbandingan rata-rata Selisih Kejadian PMS pada Mahasiswi Sebelum dan Setelah

\begin{tabular}{llllll}
\multicolumn{6}{c}{ Aerobik } \\
\hline Variabel & Klp & Mean & SD & df & $\begin{array}{l}\mathrm{p} \\
\text { value }\end{array}$ \\
\hline \multirow{3}{*}{ Kejadian } & Intervensi & & & & \\
PMS & Sebelum & 11,49 & 2,841 & 44 & 0,000 \\
& Setelah & 6,78 & 2,713 & & \\
& Perbedaan & 4,71 & 3,152 & & \\
& Kontrol & & & & \\
& Sebelum & 9,24 & 3,176 & 41 & 0,548 \\
& Setelah & $9,43-$ & 3,062 & & \\
& Perbedaan & 0,19 & 2,039 & & \\
& & & & & \\
\hline
\end{tabular}

Tabel.3 menunjukkan ratarata angka kejadian PMS Mahasiswi Jurusan Keperawatan Tangerang sebelum dilakukan senam aerobic pada kelompok intervensi adalah 11,49 dengan standar deviasi 2,841 dan setelah dilakukan senam aeorobik adalah 6,78 dengan standar deviasi 2,713. Analisa lebih lanjut adanya perbedaan bermakna antara angka kejadian PMS pada kelompok intervensi sebelum dan sesudah dilakukan senam otak dengan kata lain ada perbedaan signifikan bahwa senam aerobic dapat menurunkan rata-rata angka kejadian PMS pada mahasiswi Jurusan Keperawatan Tangerang kelompok intervensi sebesar 4,71 ( $p$ value $=0,000 \alpha=0,05)$.

Perbedaan Kejadian PMS Sesudah Intervensi antara kelompok kontrol dan Intervensi

Tabel 4

Perbandingan Rerata Angka Kejadian PMS pada Mahasiswi Antara Kelompok

Intervensi dan Kelompok kontrol setelah dilakukan intervensi di Jurusan keperawatan Tangerang Tahun 2015

\begin{tabular}{llllll}
\hline Variabel & Mean & SD & SE & df & p value \\
\hline $\begin{array}{l}\text { Kejadian } \\
\text { PMS }\end{array}$ & & & & & \\
Intervensi & 4,71 & 3,152 & 0,404 & 44 & 0,000 \\
Kontrol & $-0,19$ & 2,039 & 0,472 & 41 & 0,000
\end{tabular}

Tabel 4. menunjukkan rerata penurunan angka kejadian PMS pada kelompok intervensi adalah 4,71 dengan standar deviasi 3,152 sedangkan pada kelompok kontrol adalah peningkatan sedikit sebesar 0,19 dengan standar deviasi 2,039. Hasil analisis lebih lanjut didapatkan bahwa ada perbedaan yang signifikan selisih rerata antara kelompok intervensi dan kelompok kontrol (pvalue $=0.000, \alpha=0,05$ ), pada kedua kelompok terdapat adanya perbedaan yang signifikan, pada kelompok 
intervensi didapatkan adanya perbedaan yang signifikan menurunkan angka kejadian PMS sebelum dan sesudah dilakukan senam aerobik sedangkan pada kelompok kontrol terdapat adanya perbedaan tetapi tidak significant sehingga dapat disimpulkan bahwa senam aerobic berpengaruh terhadap penurunan angka kejadian PMS.

\section{Pembahasan}

\section{Gambaran distribusi angka kejadian PMS sebelum dan sesudah senam aerobic pada mahasiswi Jurusan keperawatan Tangerang.}

Hasil penelitian tentang distribusi angka kejadian PMS pada mahasiswi Keperawatan Tangerang sesudah dilakukan senam aerobic menunjukkan ada penurunan pada kelompok intervensi. Hal ini dilihat dari nilai rerata pada kelompok intervensi sebelum dilakukan syaitu 11,49 dan setelah dilakukan senam aerobic nilai rerata kelompok ini adalah 6,78 .

Hal itu sejalan dengan penelitian yang dilakukan oleh Nurlaela tahun 2008 penelitian yang berjudul hubungan pola olahraga, obesitas dengan kejadiam PMS. Peluang terjadi PMS lebih besar pada wanita yang tidak melakukan olahraga secara rutin.

Analisis perbedaan dilakukan untuk melihat adanya perbedaan antara kelompok intervensi dan kelompok kontrol sebelum dan sesudah dilakukan senam aerobik pada kelompok intervensi. Data menunjukkan rata-rata angka kejadian PMS Mahasiswi Jurusan Keperawatan Tangerang sebelum dilakukan senam aerobic pada kelompok intervensi adalah 11,49 dengan standar deviasi 2,841 dan setelah dilakukan senam aeorobik adalah 6,78 dengan standar deviasi 2,713. Analisa lebih lanjut adanya perbedaan bermakna antara angka kejadian PMS pada kelompok intervensi sebelum dan sesudah dilakukan senam aerobik dengan kata lain ada perbedaan signifikan bahwa senam aerobic dapat menurunkan rata-rata angka kejadian PMS pada mahasiswi Jurusan Keperawatan Tangerang 
kelompok intervensi sebesar 4,71 (p value $=0,000 \alpha=0,05$ ).

Hal itu sejalan dengan penelitian Nurlaela tahun 2008. Hasil penelitian menunjukkan peluang terjadiny PMS lebih besar pada wanita yang tidak melakukan olahraga rutin daripada wanita yang sering melakukan olahraga karena olahraga sangat berpengaruh terhadap kejadian PMS. Penelitian ini juga menyatakan bahwa aktifitas olahraga yang teratur dan berkelanjutan berkontribusi untuk meningkatkan produksi dan pelepasan endorphin. Endorphin memerankan peran dalam pengaturan estrogen. Wanita yang mengalami PMS, terjadi karena kelebihan estrogen. Kelebihan estrogen dapat dicegah dengan meningkatkan endorphin. Hal ini membuktikan olahraga yang teratur dan mencegah dan mengurangi PMS. Pada wanita yang jarang melakukan olahraga secara rutin hormone estrogen lebih tinggi sehingga kemungkinan akan terjadi PMS lebih besar.

Analisis pengaruh senam aerobic antara kelompok intervensi dan kelompok kontrol setelah dilakukan senam aerobic pada kelompok intervensi. Data diatas menunjukkan rerata penurunan angka kejadian PMS pada kelompok intervensi adalah 4,71 dengan standar deviasi 3,152 sedangkan pada kelompok kontrol adalah peningkatan sedikit sebesar 0,19 dengan standar deviasi 2,039. Hasil analisis lebih lanjut didapatkan bahwa ada perbedaan yang signifikan selisih rerata antara kelompok intervensi dan kelompok kontrol ( $p$ value $=0.000, \alpha=0,05)$, pada kedua kelompok terdapat adanya perbedaan yang signifikan, pada kelompok intervensi didapatkan adanya perbedaan yang signifikan menurunkan angka kejadian PMS sebelum dan sesudah dilakukan senam aerobik sedangkan pada kelompok kontrol terdapat adanya perbedaan tetapi tidak significant sehingga dapat disimpulkan bahwa senam aerobic berpengaruh terhadap penurunan angka kejadian PMS.

Hal itu sejalan dengan Penelitian Puji tahun 2009 bahwa senam dapat menurunkan disminore pada remaja putri hali ini terkait bahwa olahraga dapat meningkatkan 
kadar endorphin, yang merupakan suatu komponen seperti morfin yang diproduksi di otak dan dapat mengurangi rasa sakit serta menimbulkan rasa euphoria (perasaan senang dan bahagia).

Pada saat kita melakukan senam aerobik, kita akan mempunyai rasa senang karena gerakan-gerakan di dalam senam aerobik menyenangkan sehingga wanita yang melakukan senam ini mampu mengurangi stress.

Senam aerobik membutuhkan banyak energi yang banyak mengoksidasi karbohidrat dan lemak untuk memenuhi energi yang kita butuhkan, sehingga dengan melakukan senam aerobik kita dapat menjaga berat badan tidak bertambah. Semakin lama melakukan senam aerobik didapatkan gejala PMS yang muncul semakin sedikit dan melakukan senam aerobik secara teratur dalam waktu yang lama dapat mengurangi gejala PMS, hal ini kemungkinan dapat disebabkan karena tubuh memerlukan waktu untuk beradaptasi sehingga penderita baru mendapatkan pengurangan gejala PMS setelah penderita melakukan latihan senam dengan frekuensi yang lebih sering dan teratur dengan waktu yang lebih lama.

Beberapa jurnal medis membuktikan bahwa latihan aerobik juga dapat menurunkan depresi pada wanita yang mengalami PMS. Kondisi psikologis yang buruk berhubungan erat dengan kondisi fisik seseorang. Olahraga mampu membantu menstabilkan mood, kecemasan, dan depresi yang biasa terjadi pada wanita.

\section{Kesimpulan}

Berdasarkan hasil penelitian pengaruh senam aerobic terhadap angka kejadian PMS pada mahasiswa Jurusan keperawatan Tangerang.

Ada perbedaan yang signifikan selisih rerata antara kelompok intervensi dan kelompok kontrol ( $\mathrm{p}$ value $=0.000, \alpha=0,05)$, pada kelompok kelompok intervensi terdapat adanya perbedaan yang signifikan, sehingga dapat disimpulkan bahwa senam aerobic berpengaruh terhadap penurunan angka kejadian PMS. 


\section{Daftar Pustaka}

Arikunto, S. 2006. Prosedur Penelitian Suatu Pendekatan Praktik. Edisi Revisi 6. Jakarta PT. Rineka Cipta.

Harry., 2007. Mekanisme endorphin dalam tubuh.

Available at

Http:/klikharry.files. wordpress.com/2007/02/1.doc + endorphin + dalam + tubuh. Diakses tanggal 10 September 2015

Irianto, D.P. 2004. Berolahraga untuk kesehatan dan Kebugaran. Yogyakarta. Penerbit Andi

Istiqomah. P., 2009. Efektifitas Senam Disminore dalam Mengurangi Disminore pada Remaja Putri di SMUN 5 Semaranghttp://eprints.undip .ac.id/9253/, diunduh 20 Oktober 2015

Mohamad K.2007. Kesehatan reproduksi sebagai hak. Jurnal perempuan untuk pencerahan dan Kesetaraan. Yayasan Jurnal perempuan.53

Nishrina.I., Maryatun dan Wulandari., R 2012 Hubungan aktifitas olahraga dan obesitas terhadap kejadian sindrom pramenstruasi di desa Pucang Miliran Klaten. http://download.portalgaruda .org/article.php? article $=1195$ $15 \&$ val $=5466 \&$ title $=$ diunduh 12 September 2015

Nurchasanah. 2009. Ensiklopedi Kesehatan Wanita. Yogyakarta: A + Plusbooks

Nurlela., Widayati, Prabowo T., 2009. Hubungan Aktifitas Olahraga dengan Kejadian Premenstrual Syndrome. Jurnak keperawatan. 3(1); 1-5

Ressasiantina. 2010. Mengenai Hubungan antara Asupan gizi dan Pola Olahraga dengan $P M S$

http//doketr_agus.blogspot.co $\mathrm{m} / 2009 / 10 /$ diunduh $05 \mathrm{M} 3 \mathrm{i}$ 2015

Sumodarsono,S. 1998. Pengetahuan praktis kesehatan dalam olahraga. Jakarta : PT.Gramedia.

Suririnah.2007. Mengatasi PMS. Diakses tanggal 20 Januari 2015 dari http//umiserge. multply.com/journal/item/15/ mengatasi PMS Premenstrual Syndrome.

Sunaryo. 2004. Psikologi Untuk Keperawatan. Jakarta: EGC.

Sugiyono. Metode Penelitian Kuantitatif dan Kualitatif Dan R \& D. cetakan ke 7. CV Alfabeta. Bandung. 2009. 
Wartu. 2009. Manfaat Olahraga.

Diakses tanggal 22 Januari

2015 dari

http://memedaiman.multpl

y.com/journal/item/7 